\title{
A Study on Using Serious Games in Teaching German as a Foreign
} Language

\author{
Yunus Alyaz ${ }^{1}$, Dorothea Spaniel-Weise ${ }^{2} \&$ Esim Gursoy $^{1}$ \\ ${ }^{1}$ Faculty of Education, Uludağ University, Bursa, Turkey \\ ${ }^{2}$ Friedrich-Schiller University, Jena, Germany \\ Correspondence: Yunus Alyaz, Faculty of Education, Uludağ University, Bursa, Turkey. E-mail: \\ alyaz@uludag.edu.tr
}

Received: March 31, 2017

Accepted: April 16, 2017

Online Published: May 4, 2017

doi:10.5539/jel.v6n3p250

URL: http://doi.org/10.5539/jel.v6n3p250

\begin{abstract}
The interest in Digital Game-Based Language Learning (DGBLL) has increased considerably in recent years although being a relatively new approach. Despite the interest that DGBLL took, the studies in the context of German as a Foreign Language (FL) are quite limited. Moreover, DGBLL in the Turkish context is not prevalent. Due to this gap in the literature, a research project was launched at a big state university in Turkey in 2014 to explore the potentials and limitations of DGBLL. The study focuses specifically on serious games for FL teaching and learning. The aim of the project, in addition to the promotion of linguistic skills of the learners, is to contribute to the development of professional qualifications of the future FL teachers. The present research aims to report on the pilot study of the project. A one group pre-test post-test research design was used in the study. Quantitative data was collected via two opinion questionnaires implemented at the beginning and at the end of the process as well as a receptive vocabulary test. Qualitative data was collected via semi-structuted interviews and game diaries that participants kept. Two serious games for German was selected and used with traditional dictation, transcription and reading comprehension activities. The results of an 11-week gaming activity indicated significant differences between pre- and post-tests in vocabulary. Additionaly, age was found to be an important factor that affects participants' attitudes towards serious games. The results indicate that the participants found game activities useful for the development of other language skills.
\end{abstract}

Keywords: Digital Game-Based Language Learning (DGBLL), digital game-based German learning, serious games, dictation, reading

\section{Introduction}

Digital learning games (also referred to as "serious games") offer a wide range of potentials for learning FLs with their rich linguistic and cultural content, and their attractive audiovisual components. DGBLL is a current trend in the context of computer assisted language learning, which attracts the attention of both learners and teachers, schools and other educational authorities and institutions. In the past decades, numerous digital games from different genres, ranging from simple, smaller Java games to extensive games with longer scenarios were developed. These games can be used with various hardware such as PCs, tablets, game consoles and mobile phones and are especially popular among young generation. In fact, games constitute an important part of life and education. Traditional learning games such as hangman, domino, dice-anagramm, and more have already taken an important place in Foreign Language Learning (FLL) and teaching process (see Ersöz, 2000; Wright, Betteridge, \& Buckby, 1984). Many computer-assisted language learning software, e.g., "Tell me more", "Einblicke" and other popular CALL-ware from the 90s have long been included in digital learning games. In addition to multimedia-based activities and interactive exercises, these CALL-ware offered built-in small games as well, such as hangman, puzzle, etc. Moreover, the commercial adventure/entertainment games (also called Commercial Off-The-Shelf (COTS) Games) were also widely used for educational purposes (see, Gee, 2003; Prensky, 2001; Turkle, 2005) such as Foreign Language Teaching (FLT) (Coleman, 2002; Peterson, 2012; Rama et al., 2012; Stanley \& Mawer, 2008). Besides, stand-alone small games for PCs and mobile phones were developed and integrated into the FLL process (see, Browne \& Culligan, 2008; Chaka, 2009; Harriehausen-Mühlbauer, Prados, Ludwig, \& Ott, 2006); however, the scenario, the audio-visual elements, the linguistic and cultural content of these stand-alone mini games are not very comprehensive compared to COTS 
games. Purushotma (2005) reported that the linguistic content of a COTS simulation game is comparable to that of a FL course book and that it contains just as many linguistic and country-specific cultural elements as required by the FL curriculum. Inspired by the fact that these film-like, entertaining adventure games with long scenarios are played by the younger generation more often, serious games with longer stories have been designed over the last ten years, using the playful concept (gamification) of the authentic adventure games. Serious games for diverse fields present the educational content in a gamified way, for example in environmental education (e.g., Environmental Detectives), vocational training (e.g., Ludwig, Medicine) and FLL (e.g., Adventure German, SiLang, Language Trap, DigiBahn).

Deriving from the gap in the literature related to the DGBLL studies in Turkey, and as well as to contribute to the limited studies in the field this study deals with the implementation of serious games in teaching German as a foreign language. The results from the pilot study of a long-term DGBLL project, which was launched at the FL Department of a big state university in Turkey in 2014 are reported. For the pilot study two games: "Adventure German-The Mystery of the Nebra Sky Disc" (Goethe Institute, 2011) for General German and "Adventure German-A Mysterious Mission" (Goethe Institute, 2013) for German for the professional purposes were selected. The games were designed for different learning groups, language levels and learning objectives; therefore, the gaming activities were carried out with two different groups and the findings are discussed separately. This paper only involves activities that are used with the game "The Mystery of the Nebra Sky Disc" (For the results of "A Mysterious Mission" game see Alyaz \& Genc, 2016).

\section{Current State of DGBLL Research}

During the preparatory phase of the above-mentioned long-term project, a total of 130 DGBLL studies were collected and grouped into three categories: "learning and learners", "teachers" and "other" aspects of the DGBLL. The majority of the collected studies cover COTS games (80 of 130), 39 of them deal with serious games, and only 11 of them are involved with teacher aspect of DGBLL.

Studies on FLL with COTS games deal with the advantages of learning through these type of games and the effects of various player attributes on achievement. In-game and non-game factors have also been examined with regard to their influence on the learning success, and positive outcomes were often reported (Cornille et al., 2012; Gee, 2003; Kirriemuir \& McFarlane, 2004; Prensky, 2001; Rama et al., 2012; Sylvén \& Sundqvist, 2012). The number of studies on serious games has increased remarkably in the last five years: 30 of 39 serious games studies were carried out after 2010. The majority of these serious games studies (23 of 39) deal with the technical possibilities and related instructional potentials of these games; proposals for serious game development and their integration into the FLL process; as well as learner/teacher attitudes towards digital games. Neville (2010) and Sykes, Oskoz, and Thorne (2008) introduce DGBLL in their works, explaining the advantages and disadvantages of serious games and make theoretical and instructional suggestions for game design and their integration into the classroom. Cai Miller, and Seneff (2013) and Rayner and Tsourakis (2013) are concerned with the use of language-technological components (such as speech-recognition and synthesis) in serious games. In all the studies on learner opinions investigated, except De Grove, Van Looy, and Mechant (2011), high motivation and very positive learner attitudes towards the serious games were reported (see Doe, 2014; Jantke \& Hume, 2015; Howland, Urano, \& Hoshino, 2012). The effect of motivation on the attitudes of the learners and the learning success is a most frequently reported factor in the other branches of Digital Game-Based Learning (DGBL) as well (Akpinar \& Turan, 2012; Egenfeldt-Nielsen, 2005). According to Sørensen and Meyer (2007, p. 564) the reason for high motivation is the transformation "from drill-based educational material to contextualised simulations that involve fruitful thinking, real language interaction and student engagement".

In these studies, besides high motivation, also immersion and learner autonomy were mentioned as key factors in the success of DBGLL (Boyle et al., 2011; Robertson \& Howells, 2008; Stewart, Bleumers, Van Looy, Mariln, All, Schurmans, ... Misuraca, 2013). In 16 empirical studies on serious games, as well as in the studies on learning through COTS games, the effects of players' sociodemographic characteristics (e.g., age, gender, game competency, attitudes, gaming preferences and frequency), in-game (e.g., scenario, multimedia), and non-game factors (e.g., motivation, autonomy, immersion, interaction, etc.) on learner success showed positive correlations. Researchers also reported positive outcomes in vocabulary, listening comprehension, speech fluency, reading comprehension, grammar, and writing skill (see, Bernert-Rehaber \& Schlemminger, 2013; Berns, Palomo-Duarte, Dodero, \& Valero-Franco, 2013; Kocaman \& Kizilkaya-Cumaoglu, 2014; Levy \& O'Brien, 2006; McInnis, 2009; Müller, 2012; Neville, 2015; Peirce \& Wade, 2010; Roy \& Schlemminger, 2014). According to Levy and O'Brien (2006), the tasks in the virtual world offer the learner a good opportunity for 
real-like experiences in the target culture as well. Guillén-Nieto and Aleson-Carbonell (2012) used English learning games to promote linguistic proficiency and to provide cultural information about the country and reported that most learners were enthusiastic and highly motivated, were fully involved in the game activities. The results showed significant differences between the pre- and post-test related to intercultural communication skills.

Furthermore, in the DGBLL studies, the attitudes of teachers as well as prospective teachers towards using digital games at different school levels were also examined. Some of the research report positive results regarding the teachers' attitudes toward serious games (see, Millstone, 2012; Karadag, 2015; Noraddin \& Kian, 2013), yet some studies state that this is not the same condition for commercial adventure games (see, Yilmaz-Ince \& Demirbilek, 2013).

As opposed to the positive results regarding the use of digital games some research also reported some negative results. For instance, Bradshaw and Nichols (2004) argued that the decline in reading rates is parallel to the rise of various electronic media, including the Internet, video games, and portable digital devices. Various studies reported that although there is an increasing interest among teachers, there is also a resistance to use digital games in the classroom (Allsop et al., 2013; Blamire, 2010; Egenfeldt-Nielsen, 2005; Emin-Martinez \& Ney, 2013; Wagner \& Mitgutsch, 2009). As for the reasons of this resistance, difficulty of integrating the digital games into curricula, the lack of infrastructure, negative responses from evrionment (e.g., colleagues, local authorities, parents, etc.) as well as the discrepancy between length of the lessons and games can be mentioned. Researchers explain the negative attitude of teachers with the intergenerational conflict due to the digital literacy gap between them (Lacasa et al., 2008; Sandford, Ulicsak, Facer, \& Rudd, 2006; Turkle, 2005). It is stated that a significant number of teachers do not play video games, while the majority of students play various kinds of digital games in their spare time. Moreover, Chandler (2013) claims that teacher education curricula does not focus on games thus it is only the innovative educators who use them in their classes.

Although the DGBLL studies provide wide-ranging teacher attitudes regarding the integration of digital games into language teaching process, the negative and uncertain teacher attitudes are predominant. In order to change negative attitudes into positive, other related obstacles, in addition to the above mentioned concerns, must be overcome before the use of digital games in the classrooms, e.g., solving hardware and software-related technical problems (such as plug-in/operating system incompatibility, limited storage/memory capacity of mobile devices etc.), game license fees (see Wastiau, Kearney, \& Van den Berghe, 2009), the concern of parents or teachers about the possible negative effects of digital games such as addiction, time-sink, and possible glorification of violence, which are normally only discussed in the context of adventure games.

\section{Learning Materials and Activities}

An examination of the appstores for mobile devices showed that there are about 110 German applications offered for mobile devices. Only 17 of these are games and only two of them are language learning games in the form of an authentic adventure game. These are "Adventure German - The Mystery of the Nebra Sky Disc" and "A Mysterious Mission". These two games differ from the remaining applications and games in terms of the target group and the complexity of the content. Both have been designed for adult learners and have a rich content, while all other applications and learning games have been designed for younger learners and are offered with relatively limited content, e.g., in the form of specific grammar, vocabulary trainers (so-called small games) Even with the PC games, the situation is no different: The analysis has shown that there are several hundred small, but only two extensive German language games for PCs (Language Trap and DigiBahn), which are offered or played over the Internet free of charge via the website of the Goethe-Institute. Thus for the pilot study "Adventure German-The Mystery of the Nebra Sky Disc" and "A Mysterious Mission" were chosen. The linguistic content of the role play game "The Mystery of the Sky Disc" is equivalent to level A1-A2 and can be played with mobile devices and PCs with various operating systems offline and online. In the game the player acts through an avatar at eleven different locations (airport, hotel, supermarket, museum, university, forest, etc.) and manages the typical communicative language situations in Germany. The dialogues between the virtual game characters, correspondences, explanations, newspaper articles and game instructions form 27 A4 pages of game scenario, which contains a total of 7,366 words by repetitions of 687 individual words. The player follows the instructions of the game guide, has to answer questions (in the form of fill-in-the-gaps, combination, etc.) and learn cultural information about Germany. The game contains dialogical and monological listening and reading texts in the standard German variety (Hochdeutsch) and has rich Germany-specific cultural information. Since the player gets to know Germany in an exciting adventure and in everyday situations (e.g., hotel reservation, restaurant visits, directions, cooking from recipes), the language content can help the learner traveling to 
Germany. The game instructions are delivered optional in German, English and Turkish, the game content remains German in all language options.

The game activities were planned for eight weeks in the spring semester of 2015 with pre-service German teachers in their first year of study as a part of Computer lessons. Computer course consists of two hours of theory and two hours of practice, and aims the investigation, use and development of digital media of all kinds (text, audio, film, presentation, language learning software, etc.), introduction to the computer-assisted language learning theory and its possible applications. In this sense, digital games are seen as CALL-ware within ICT courses. The majority of the students $(80 \%)$ participated in the game activities voluntarly, whereas $20 \%$ were unsure, but nevertheless participated. Pre-service teachers who did not want to participate in the game were offered alternative tasks such as digital film production. The participants played the game out of classroom and the game process report (player experiences, problems, etc.) was submitted via a forum tool of the Learning Management System (LMS) "UKEY" in written form and discussed orally in the last 15 minutes of the ICT class hours.

\subsection{Traditional Transcription, Dictation, and Reading as DGBLL Activities}

Since there is relatively little experience reported about the intergration of digital games into the curriculum there isn't any standard practice. Hence practice related difficulties often rise during the integration of digital games into the teaching process. The DGBLL studies show that teachers worldwide have attempted to combine various in and out of class, as well as individual and group activities. These include: playing outside the lessons (Berns et al., 2013; Howland et al., 2012; Peirce \& Wade, 2010), extramural game activity and repeated game play (e.g., playing each chapter five times, Doe, 2014), playing in the classroom according to the instructions of teacher (Guillén-Nieto \& Aleson-Carbonell, 2012; Kocaman \& Kizilkaya-Cumaoglu, 2014), combining classroom activities with play activities, e.g., game as homework (Neville, 2015) and many others. In most of the game projects, the participating players were given individual activities outside the school. The participants of this study also played the game "The Mystery of the Nebra Sky Disc" in extra curricular times and alone, since the game is designed for single players only. The participants are given a series of work instructions for playing the game. They were requested to write down the spoken dialogues (dictation/transcription) during the game, to write the written texts reproductively, in order to combine them with the game text as part of the ICT and material design seminar during the next academic year to create an illustrated, exercise book for the game.

Dictation, transcription, and reproductive writing as learning, training, and examination activities are not new; but what is new to the considerations in this implementation is the combination with a serious game. The function and contribution of the dictation for FLT have long been known. There are numerous studies which report that during dictation almost all aspects of linguistic communication are taken into account from phonological, grammatical to lexical knowledge, thus concluding that the dictation is a positive method for training linguistic skills (Buck, 2001; Coniam, 1995; Oller, 1979). The dictation is also of great importance in terms of the hypotheses of Krashen (1985), and is offered as an activity in present German course books (e.g., Menschen, Schritte International), for learning, training, consolidation and testing purposes (Fisher, 2011; Mei, 2013; Pawłowska, 2012). The function and the contribution of reproductive writing to the promotion of the writing skill in the mother tongue as well as the FL context are well known (Neugebauer \& Nodari, 1999; Piechotta \& Beck, 2006). A look into contemporary German course books shows that reproductive writing tasks are offered in varying degrees. The transcription as an audiovisual form of the dictation is used in the language classes that use films as a material for presentation, practice, consolidation and testing purposes.

The dictation, writing and transcription activities presented here were adapted to the serious game, so that the students are able to repeat the learning content. The effectiveness of automated language exercises earned by repetition has also been emphasized more often recently (see, Funk, 2011). At the end of the eight weeks of game activies, the original text of the game was given to the participants so that they could compare their own texts (and prepare their exercise book for the game planned for the next year). The game text has been dealt with in the classroom by means of text comprehension strategies (global, selective and detail comprehension through explanations and questioning, etc.), as is also the case in traditional reading lessons. As three-quarters of the 27 pages of the game text consist of short dialogues and correspond to the A1-A2 level, the whole text, which was already known to the players in the game phase through writing tasks, was processed in three weeks (six lesson hours). It must be noted here that the participants' language level (A2-B1) was slightly higher than the one suggested for the game. 


\section{Method}

A one group pre-test post-test research design was implemented in the study. Data for this study was collected via triangulation in five different steps to find answers to the following research questions;

1) Is there an increase in the vocabulary size of the paritcipants after the game activities?

2) Do the sociodemographic variables such as age, gender, language preferences, playing habits and opnions towards using digital games in educational context have an effect on achievement?

3) How do serious games contribute to the development of participants' linguistic skills and knowledge on target culture?

4) How do the use of diverse forms of tasks and exercises, such as dictation, transcription and reading activities, contribute to the learning process?

5) Does playing serious games individually increase the motivation to use such digital media in participants' future profession?

\subsection{Data Collection Instruments}

Data for the study is collected by using both written surveys and interviews: two written questionnaires, a vocabulary test (before-after), game diaries and focus group interviews. Collected data were analyzed with quantitative and qualitative methods. The first group of quantitative data were collected via a questionnaire that aimed to inquire about the socio-demographic attributes of participants, as well as their opinions toward and experiences with technology and digital games. The participants completed the questionnaire at the beginning of the semester in German.

At the end of eleven weeks of gaming activities (eight weeks for playing and three weeks for reading activities in the classroom), a second questioannaire was conducted, with which the participants evaluated the technical features of the game (e.g., user-friendliness, multimedia elements, etc.), linguistic content and the effectiveness of reproductive writing and reading activities. They were also asked whether they would use digital games with their future learners. The responses to 23 items were recorded on a Likert scale $(5=$ completely agree, $1=$ completely disagree). The questionnaire was found reliable with .78 alpha value.

In order to determine the vocabulary learning success of the participants, a vocabulary test was prepared, that contained items from the game narrative and applied before and after the game activities. Since the participants already had knowledge of German, simple words and expressions such as greeting forms, basic grammatical elements (e.g., prepositions, modal verbs, etc.) were eliminated and the remaining 415 items (200 nouns, 123 verbs and 92 other word classes [Adjectives, Conjunctions, etc.]) were used in the vocabulary test. In addition, some new terms from the field of technology (e.g., die Drohne=drone), are included in "Profile Deutsch" register at A1-A2 level (Glaboniat, Müller, Rusch, Schmitz, \& Wertenschlag, 2008). The vocabulary test, prepared as an Excel file, was given to the students via the Learning Mamagement System (LMS) "UKEY" and they were asked to give Turkish equivalents.

A game diary was used as another data collection tool. Students were given the task to document their gaming experiences, difficulties and problems, the daily/weekly playing time as well as newly learned words and structures, country-specific information, in-game language exercises and dictionary use. The game diaries were submitted to the lecturer via the "UKEY LMS".

At the end of the semester the game process was also evaluated by semi-structured, focus group interviews with the participants. On the basis of a semi-structured interview, data were collected on the following seven points: game diary entries (playing and learning experiences, playing time, newly learned words/structures, in-game exercises, difficulty of language level of the game), performed activities, opinions towards digital games.

\subsection{Data Analysis}

The descriptive statistics were conducted using, SPSS (21.0). One-way analysis of variance (ANOVA) was conducted to evaluate the relationship between participants' demographic variables and success scores since Levene Test has indicated that the variances of scores across examined groups are homogeneous. Focus group interview results were analyzed according to pre-determined categories. Information regarding seven issues were grouped under related categories.

\subsection{Paticipants}

The game was played by 58 pre-service teachers (43 females and 15 males) aged 18-26. The participating pre-service teachers' language level was between A2-B1 and they started learning German as a FL in high 
school ( 2 hours a week for 4 years). Focus-group interviews were conducted with 30 participants. All of the participants studied in the preparatory class of the School of Foreign Languages (during 2 semesters, 24 hours per week) before they started German as a FL Department. They, therefore, formed a relatively homogenous group with regard to their language skills and language learning background. The information on the participants' owned hardware, Internet access and game preferences are presented in Table 1.

Table 1. Owned digital devices, internet connection and game preferences of the participants

\begin{tabular}{lll}
\hline & Smartphone & $100 \%$ \\
& Tablet & $34.4 \%$ \\
Hardware ownership and & PC & $41.4 \%$ \\
Internet Accsess & Laptop/Notebook & $39.7 \%$ \\
& Game Console & $21.3 \%$ \\
& Internet connection (ADSL \& mobile) & $72.4 \%$ \\
& (only mobile) & $27.6 \%$ \\
\hline \multirow{3}{*}{ Game Preferences } & Plays digital games & $93.1 \%$ \\
& Playing time (Hrs./Week) & $0-10(\tilde{=} 3.5 \mathrm{hrs})$. \\
& COTS/MMORPG & $32.7 \%$ \\
& Small Games & $65 \%$ \\
& Word Games & $19 \%$ \\
& Serious Games & - \\
\hline
\end{tabular}

Table 1 shows that serious games do not belong to the playing activities of the participants. The survey also showed that participants have not played digital games in any other course at the university or before.

\section{Findings}

In order to answer the first Research Question (RQ), the vocabulary size of the participants was compared through pre- and post-tests, and the distribution of the word groups (nouns, verbs and other word classes) was examined. The mean value in the pre-test was 302 words and 337 words in the post-test. In order to determine the individual vocabulary learning performances, word scores of the participants were calculated by using the following formula [(total correct responses of participant/the total number of words)x100]) and defined as the learning performance of the participants. The vocabulary learning performance scores are illustrated in Figure 1.

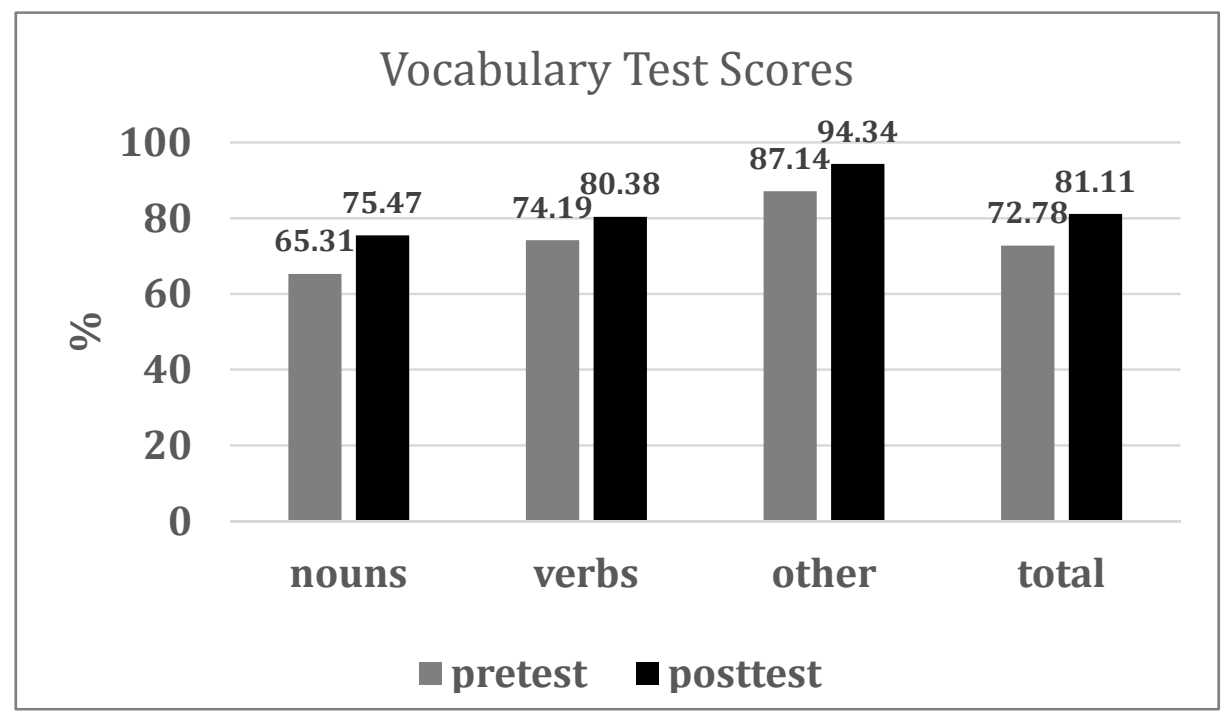

Figure 1. Learning performance of the participants in the vocabulary test 
Figure 1 shows a vocabulary performance value of $72.78 \%$ before and $81.11 \%$ after the game activities. The participants gained the highest learning achievement in the "other word groups", which is followed by "verbs" and "nouns" respectively. According to the results of paired-samples t-test, there is a statistically difference between the pre-test $(\mathrm{X}=72.78, \mathrm{SD}=7.3)$ and post-test scores $(\mathrm{X}=81.11, \mathrm{SD}=6.9)$ for all word classes $(\mathrm{t}(57)=-17.41, \mathrm{p}=.000)$.

To answer the second RQ, the relation between the sociodemographic attributes of the participants and their performance was examined. As the age of the subjects is close to each other, the age variable was divided into three groups (18-19, 20-22 and 23+). Table 2 shows the performance values of each age group in the pre- and post-test.

Table 2. Descriptive statistics of the mean scores of the age groups

\begin{tabular}{lccccc}
\hline & & \multicolumn{2}{c}{ Pre-test } & \multicolumn{2}{c}{ Post-test } \\
\cline { 3 - 6 } Age groups & $\mathrm{n}$ & Mean score & SD & Mean score & SD \\
\hline $18-19$ & 29 & 68.43 & 5.54 & 76.54 & 5.87 \\
$20-22$ & 27 & 76.39 & 5.82 & 85.25 & 4.09 \\
$23+$ & 2 & 87.23 & 2.72 & 91.57 & 1.70 \\
Total & 58 & 72.78 & 7.33 & 81.11 & 6.87 \\
\hline
\end{tabular}

The descriptive statistics in Table 2 indicate a relation between the age and the performance scores in the preand post-test, that is, the higher the age of the participants, the better the results in pre- and post-test.

Table 3. ANOVA Table for comparison of post-test scores among age groups

\begin{tabular}{lccccc}
\hline Test & $\begin{array}{c}\text { Sum of } \\
\text { Squares }\end{array}$ & df & Mean Square & F & P \\
\hline Between Groups & 1285.67 & 2 & 642.84 & 25.15 & .000 \\
Within Groups & 1406.02 & 55 & 25.56 & & \\
Total & 2691.69 & 57 & & & \\
\hline
\end{tabular}

The results of the ANOVA analysis in Table 3 indicate that the difference between the performance scores of age groups in the post-test is significant $(\mathrm{F}[2,57]=25.15, \mathrm{p}=.000)$ and the Scheffe test showed that mean scores of the youngest age group were statistically lower than the other age groups.

In order to find out any relation between performance in the vocabulary post-test and participants' opinions to use serious games in their future teaching profession, a one-way ANOVA was used. The results show significant differences between the vocabulary post-test mean scores of the participants $(F[2,57]=33.27, p=.000)$. According to the Scheffe test, the vocabulary performance scores of participants who 'strongly agree' to use the serious games in their future classes is significantly higher than the other groups. This means that the willingness to use serious games in the future profession increases with vocabulary learning success. When the pre- $(\mathrm{X}=3.81$, $\mathrm{SA}=.48), \mathrm{t}(57)=-17.41, \mathrm{p}=.000)$ and post-test $(\mathrm{X}=4.36, \mathrm{SA}=.67)$ results regarding the willingness to use digital games in the future examined it is seen that there is a significant increase in the post-test.

The participants also evaluated the serious game in nine aspects (Table 4). Accordingly, the mostly agreed three aspects were preference to traditional course materials, adequacy of the language level and game scenario respectively. 
Table 4. Evaluation of the game

\begin{tabular}{lccc}
\hline Game element & $\mathrm{N}$ & $\mathrm{X}$ & $\mathrm{SD}$ \\
\hline Preference to traditional materials & 58 & 4.28 & .59 \\
Language level & 58 & 4.26 & .55 \\
Scenario & 58 & 4.03 & .46 \\
Challenge & 58 & 3.86 & .39 \\
Easy to play & 58 & 3.81 & .69 \\
Visual design & 58 & 3.64 & .74 \\
Entertaining & 58 & 3.45 & .63 \\
Soundtrack & 58 & 3.16 & .62 \\
Action/Adventure & 58 & 2.98 & .13 \\
\hline
\end{tabular}

The participants were also asked to evaluate dictation, transcription, and reading activities and their contribution to language (Table 5). The participants are relatively unanimous in their evaluation of the dictation as the most difficult activity, followed by transcription and lastly, reading comprehension. As can be seen in Figure 2, the evaluation mean values follow dullness and efficiency in the same order. The dictation was rated by the students as the most difficult and boring, but at the same time the most effective activity.

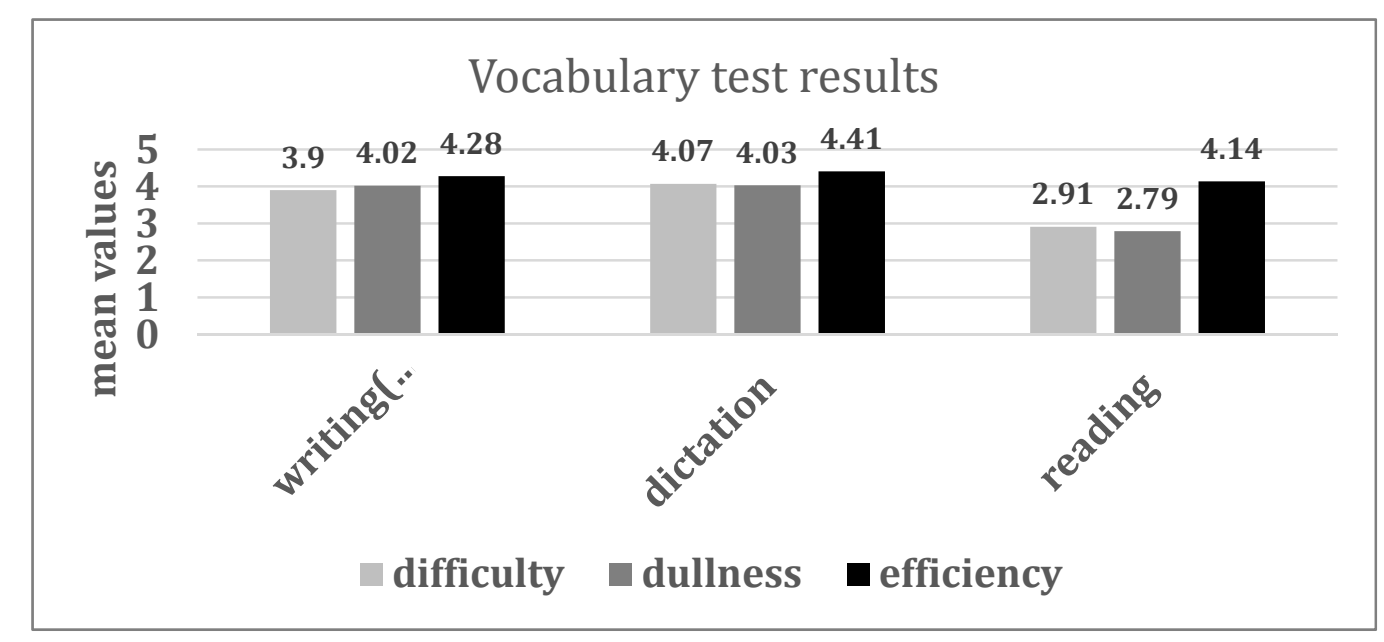

Figure 2. Evaluation of the game-combined writing tasks

According to the findings shown in Table 5, the participants find the dictation, transcription and the reading activities especially useful for the development of the vocabulary, writing, listening comprehensions and learning target culture.

Table 5. Students' opinions on the contribution of the writing tasks to the development of language skills

\begin{tabular}{lccc}
\hline Skills & N & X & SD \\
\hline Vocabulary & 58 & 4.27 & .74 \\
Writing & 58 & 4.10 & .63 \\
Listening & 58 & 4.07 & .67 \\
Speaking & 58 & 3.41 & .49 \\
Pronounciation & 58 & 3.29 & .67 \\
\hline
\end{tabular}




\begin{tabular}{lccc}
\hline German culture & 58 & 3.53 & .59 \\
Grammar & 58 & 2.90 & .55 \\
\hline
\end{tabular}

The experiences of the participants during playing were documented via game diaries they kept. According to these, eleven participants had hardware-based technical problems with downloading or while playing the game on a mobile phone. However, the problem was solved either by playing the game with tablet computers $(n=4)$ or online $(\mathrm{n}=7)$. The rest could play the game on their mobile phones easily. All students reported that they had completed the writing tasks with a PC or a laptop, that is, smartphones and tablets were not used for word processing purposes. Only six players preferred English as game instruction language and the remaining 52 players chose German. The analysis also showed that the game could be played in 6-11 hours, and all participants have played the game at least twice. In the newly learned words field 12 to 22 words have been entered. Entries for dictionary use show that $3.4 \%$ of participants stated that they used on-line dictionaries during the entire playing time, $10.3 \%$ used it often and $58.6 \%$ rarely, yet, $27.6 \%$ didn't respond at all. No entry was made for the learned structures/utterances and in-game language exercises. In terms of learned cultural information 7 to 10 elements were written (e.g., hotel reservation and registration, ordering food in a restaurant, paying, tip, currency, cooking culture like rote Grütze, unknown city/river names, art museum, history, university campus). As the entertaining, motivating feature of the game, the visual design (47.3\%), the soundtrack (21\%) and the action scene at the end of the game (67\%) were reported.

A few players (19\%) stated in their diaries that they had great difficulties with writing because it slowed down playing the game. $56.9 \%$ had difficulties in following and understanding conversations in some sections that have no subtitles (e.g., the cooking recipe for rote Grütze, the announcements in the waiting room, etc.), 25.9\% didn't mention any difficulties. The majority (43\%) evaluated the challenge level as 'easy' except for the final mission.

At the end of the semester, the whole game process was evaluated through a semi-structured focus group interview in the classroom. The experiences and opinions of the participants were collected on the following seven points:

1) Background on serious games and gaming experience: During the interview, students were asked to give other examples of serious games. The interview results showed that none of the participants had heard about this type of games. A few participants $(\mathrm{n}=4)$ considered classic, small games like hangman, word games, scrabble-puzzle, etc. as "serious games". As a support to diaries, the players claimed that none of them encountered any great technical difficulty, stating that the game can be played without deeper IT experience.

2) Playing time: The interviewees indicated that playing time ranged between 4-11 hours, which was also supported by the game diaries. Moreover, all players stated that they played the game at least twice.

3) Entry of newly learned words/structures: In the interview the participants were asked the reasons for noting only a few words although the game contains a lot of new words for the target group. The answers to this question was grouped under two themes as "disruptive nature of the process" $(\mathrm{n}=5)$ and "time consumption" $(\mathrm{n}=7)$. The interviewees explained that this was because they found it disruptive and time-consuming to take screenshots, record every unknown word with the sentence it occurs, as well as writing its Turkish equivalent. So, some decided to look for the new words in an online dictionary and continued to play without noting all of them. But this does not apply to the structures they have learned in the game. No new structures were entered into the diaries. According to some participants, this was because they had learned all the grammatical structures well in high school, the intensive preparatory class, and Grammar I and II courses.

4) Doing in-game exercises: The participants had negative feelings regarding in-game exercises and found them redundant as they did this while recording new vocabulary items. As one of the interviewees stated: "I did not note any exercises in the diary, because I simply found it superfluous".

5) Language level of the game narrative: The majority of the participants $(n=18)$ evaluated the language level as easy as seen in the following quotation: "The game instructions are clear; most unknown words occur in the story of the game. In general, the game narrative and the exercises were understandable for me".

6) Combined Activities: In the interview it became clear that especially dictations were very complex. A lot of participants complained about the time spent on dictation. One participant said that the dictation and the transcription were so slow that she often wanted to give up and thought about switching to an alternative task 
(creating a digital short film). Although most participants $(n=21)$ found these activities too difficult, no one had given up and the opinions on the efficiency of these activities were ultimately positive.

7) Using digital games in their future classes: The question whether the participants would use the digital games as course material for their future teaching provided interesting answers. They explained their opinions with the advantages of the learning with games in terms of their ubiquitousness and omnipresent playability $(n=13)$, personalized playing (learning) time, length, and pace $(n=9)$, and the high entertainment value $(n=6)$ compared to printed textbooks and other traditional media. A student who was uncertain about the use of digital games in his future German classes argued that this game is quite different from authentic adventure games in terms of action and challenge. Therefore, he was unsure whether his future students (younger learners) would find such games attractive.

\section{Discussions}

In this study, the results of the pilot phase of a long-term DGBLL project at a big state university in Turkey were presented using the example of the German learning game "Adventure German-The Mystery of the Nebra Sky Disc". The participants, pre-service teachers at the German department, were asked to carry out two different roles: as German language learners while playing and as (future) German teachers when evaluating it. This dual role provided important insights into the usability and evaluation of the digital games for the FLL.

The first RQ inquired about the possible vocabulary gain. The results indicated significant differences in vocabulary pre- and post-tests. Thus the findings are in line with the previous literature that serious games have a positive effect on vocabulary acquisition (Berns et al., 2013; Kocaman \& Kizilkaya-Cumaoglu, 2014; Müller, 2012).

As investigated with the second RQ, the results regarding the impact of sociodemographic attributes of the participants on their vocabulary learning success was diverse. It was found that among the demographic characteristics only the age and the attitude of the participants towards the use of digital games in the German courses has an influence on the vocabulary learning success. The older students have outscored the youngest in the vocabulary pre- and post-test, and those with a more positive attitude have outscored the participants with a less positive and with an uncertain attitude. In previous studies it was pointed out that children and adolescents of the digital generation, the so-called digital natives, are better than adults in digital game-based language learning (Jantke \& Hume, 2015; Peirce \& Wade, 2010). The participants of these previous studies were younger learners, which have shown a reverse relationship between age and DGBLL success. Thus the positive relationship between age and learning success obtained in this study can not be related to the previous findings since the age group investigated in this study (18-26 years) is different from the others. In addition, other factors such as sense of responsibility and other individual characteristics may have played a role in success. For example, most participants rated the location and time-independent gaming and learning opportunities positively and thought they would prefer digital games to the traditional materials. The effect of the most frequently cited factors about the issue are the motivation and autonomy on vocabulary learning success (Boyle et al., 2011; Robertson \& Howells, 2008; Stewart et al., 2013). The motivation factor can also explain the higher vocabulary performance values of the participants who have agreed to use digital games in their future German courses.

The third RQ aimed to investigate the contribution of digital games to the development of language skills. The positive assessment of the "learning adventure game" has shown that it is not only useful for the vocabulary, but also for the development of all language skills, except grammar, and learning cultural information. The result might be due to several factors such as participants' advanced grammar knowledge and meaning-focused nature of game content rather than form. Moreover, the participants' previous background on studying German might have a role in the lack of development in cultural information probably because they already posses it.

The results of this study on the evaluation of the external activities showed that participants found dictation and transcription as the most difficult activities. Compressing game activities to eight weeks made it difficult to write down the relatively long game text and exerted a time pressure on the participants. However, the results of the same evaluation and in-class interviews showed that, despite their difficulty, they found these activities as useful for the vocabulary acquisition, the development of multiple language skills and learning cultural elements. This answer to the fourth RQ is consistent with the results of the previous research such as Neville (2015), Levy and O'Brien (2006), Berns et al. (2013), Guillén-Nieto and Aleson-Carbonell (2012). Although the vocabulary learning performance scores did not differ significantly depending on the difficulty level, the high mean scores of the participants indicated that the adventure German game and the combined dictation, transcription and reading comprehension activities are useful for developing language skills in German class despite the heavy time pressure. 
The significant difference between pre- and post-test mean scores regarding students' opinion of using digital games in their future classes as a teaching and learning material is an expected result and agrees with the results of previous research on teachers' opinions (Karadag, 2015; Millstone, 2012; Noraddin \& Kian, 2013; Yilmaz-Ince \& Demirbilek, 2013). The result related to the fifth RQ indicate that active participation in game activities has a positive effect on prospective teachers' motivation to use them in the future.

\section{Conclusions and Suggestions}

The present study aimed at investigating the effects of traditional activities when integrated with digital games. For this purpose, the participants' vocabulary development was examined. Moreover, the participants were asked to evaluate the game process as well as their language skills' development. The results of the study on vocabulary learning indicated development. Most of the studies regarding DGBLL were focused on young language learners. The positive opinions of the participants to use digital games have shown that they can be attractive for adult learners as well. The current research, to the authors' knowledge, is the first to inquire about adult participants' playing experiences who will become language teachers. The previous studies considered teachers' opinions without requiring their playing experiences. For that matter, the results of the study are important as it sheds some light to the literature of DGBLL by involving pre-service teachers and by focusing on their gaming experiences.

Compared to the adventure games, the serious games, despite their multimediale attractions and rich content are not yet part of the everyday life of pre-service teachers for this specific context. This indicates a need to introduce such material to future teachers during teacher education, even if these are originally designed for out-of-school learning. The integration of the serious games into the FL classes can also ensure teachers' support in improving students' linguistic knowledge. The positive results indicate a need for more DGBLL to enrich the language learning environments. Thus this need would result in producing more serious games which would provide an opportunity for the teachers and learners to select appropriate ones for their needs.

DGBLL is a relatively young approach and empirical studies on the use of games in the classroom with adults are hardly available. In order to optimize the efficiency of digital games in the classroom, it is recommended to integrate them into the classroom systematically and to work on activities following the instructional 3-step (before, during and after the game) procedure as it is common in film activities. At universities, courses such as Language Learning through (traditional) Games' have long been offered. These may also include digital games, as their content and activities correspond to the recommendations of the Common European Framework of Reference for Languages (CEFR) in linguistic as well as language and media-aesthetic learning objectives.

As the study shows, this is only a first attempt to combine the serious games with the traditional language learning activities in the classroom. Despite the reported results concerning the success in the receptive vocabulary and the attitude of the participants to the digital games in general and serious games, they can neither replace the traditional FL instruction nor its traditional activities or materials, but, like all CALL applications and materials, they merely have a complementary, enriching function. To this end, the study has implications for FL learners, pre-service teachers, teachers, curriculum developers, educational institutions and serious game developers.

More comprehensive and comparative studies will be conducted within the framework of the above-mentioned long-term project over the next years with German, English and French learners to contribute to a better understanding of the results of this study. The following questions are at the center of interest: Should digital games become a new content of FL teacher training? What kind of tasks and exercise activities in the classroom should be developed in order to integrate the digital games into the learning process successfully? How can classroom and out-of-classroom activities be combined effectively? To this end, the question posed by Backlund and Hendrix (2013) must be answered whether learning with digital games has an impact on the short or long-term success of the learner. Results on the impact of digital games will improve our knowledge of the requirements and challenges of the DGBLL in the context of teacher training and lifelong learning.

\section{References}

Akpinar, Y., \& Turan, M. (2012). Designing a collaborative learning game: Its validation with a turntaking control scheme in a primary science unit. Education and Science, 37(163), 254-267. Retrieved from http://egitimvebilim.ted.org.tr/index.php/EB/article/download/1241/352

Allsop, Y., Yeniman-Yildirim, E., \& Screpanti, M. (2013). Teachers' beliefs about game based learning: A comparative study of pedagogy, curriculum and practice in Italy, Turkey and the UK. In P. Escudeiro, \& C. Vaz de Carvalho (Eds.), The Proceedings of The 7th European Conference on Games Based Learning 
(ECGBL 2013) (pp. 1-10). Porto, $\quad$ Portugal. $\quad$ Retrieved from https://issuu.com/acpil/docs/ecgbl2013-issuu_vol_1

Alyaz, Y., \& Genc, Z. S. (2016). Digital game-based language learning in foreign language teacher education. TOJDE, 17(4), 130-146. http://dx.doi.org/10.17718/tojde.44375

Backlund, P., \& Hendrix, M. (2013), Educational games-Are they worth the effort? A literature survey of the effectiveness of serious games. In The Proceedings of 5th International Conference on Game's and Virtual Worlds for Serious Applications (pp. 1-8). Bournemouth, Dorset, UK. Retrieved from https://doi.org/10.1109/VS-GAMES.2013.6624226

Bernert-Rehaber, B.-R., \& Schlemminger, G. (2013). Immersive 3D-Technologien optimieren das Fremdsprachenlernen: EVEIL-3D-Lernen in virtuellen Welten. Babylonia, 3, 44-49. Retrieved from http://babylonia.ch/fileadmin/user_upload/documents/2013_3/Bernert-Rehaber_Schlemminger.pdf

Berns, A., Palomo-Duarte, M., Dodero, M. J., \& Valero-Franco, C. (2013). Using a 3D Online game to assess students' foreign language acquisition and communicative competence. In D. Hernández-Leo, T. Ley, R. Klamma, \& A. Harrer (Eds.), Scaling up Learning for Sustained Impact (pp. 19-31). Berlin, Heidelberg: Springer. https://doi.org/10.1007/978-3-642-40814-4_3

Blamire, R. (2010). Digital games for learning-Conclusions and recommendations from the IMAGINE project. Retrieved from http://recursostic.educacion.es/blogs/europa/media/blogs/europa/informes/IMAGINE\%20 Conclusions\%20and\%20recommendations\%202010-3.pdf

Boyle, E., Connoly, T. M., \& Hainey, T. (2011). The role of psychology in understanding the impact of computer games. Entertainment Computing, 2, 69-74.

Bradshaw, T., \& Nichols, B. (2004). Reading at risk: A survey of literary reading in America. In D. Ball (Ed.), Research Division Report \#46. Washington, DC: National Endowment for the Arts. Retrieved from https://www.arts.gov/sites/default/files/ReadingAtRisk.pdf

Browne, C., \& Culligan, B. (2008). Combining technology and IRT testing to build student knowledge of high frequency vocabulary. The JALT CALL Journal, 4(2), 3-16. Retrieved from http://journal.jaltcall.org/articles/4_2_Browne.pdf

Buck, G. (2001). Assessing listening. Cambridge: CUP.

Cai, C. J., Miller, R. C., \& Seneff, S. (2013). Enhancing speech recognition in fast-paced educational games using contextual cues. In P. T. Badin, H. G. Bailly, D. Demolin, \& F. Raby (Eds.), Proceedings of the Workshop on Speech and Language Technology in Education (SLaTE, 2013) (pp. 54-59). Grenoble, France. Retrieved from https://groups.csail.mit.edu/sls/publications/2013/Cai_SLaTE_2013.pdf

Chaka, C. (2009). Portable handheld language learning from CALL MALL to PALL. In R. de Cássia, V. Marriott, \& P. L. Torres (Eds.), Handbook of Research on E-Learning Methodologies for Language Acquisition (pp. 539-553).

Chandler, C. (2013). The use of game dynamics to enhance curriculum and instruction: What teachers can learn from the design of video games. Journal of Curriculum and Instruction, 6(2), 60-75. Retrieved from http://www.joci.ecu.edu/index.php/JoCI/article/view/226/pdf

Coleman, D. W. (2002). On foot in SIM CITY: Using SIM COPTER as the basis for an ESL writing assignment. Simulation \& Gaming, 33(2), 217-230.

Coniam, D. (1995). Computerized dictation for assessing listening proficiency. CALICO Journal, 13(2\&3), 73-85. Retrieved from https://calico.org/html/article_601.pdf

Cornillie, F., Clarebout, G., \& Desmet, P. (2012). Between learning and playing? Exploring learners' perceptions of corrective feedback in an immersive game for English pragmatics. ReCALL, 24(3), 257-278.

De Grove, F., Van Looy, J., \& Mechant, P. (2011). Comparing the potential of commercial off-the-shelf and educational games video games for adult foreign language education: An experimental study. In D. Gouscos, \& M. Meimaris (Eds.), Proceedings of the 5th European conference on games-based learning (ECGBL 2011) (pp. 129-136). Athens, Greece: National Kapodistrian University of Athens. Retrieved from https://biblio.ugent.be/publication/1997787/file/6764995.pdf 
Doe, R. J. (2014). Lost in The Middle Kingdom: Teaching new languages using serious games and language learning methodologies (Master's thesis). University of South Carolina, Columbia, USA. Retrieved from http://scholarcommons.sc.edu/etd/2813

Egenfeldt-Nielsen, S. (2005). Beyond Edutainment-Exploring the educational potential of computer games (Doctoral dissertation). IT-University of Copenhagen, Denmark. Retrieved from http://education.ucf.edu/insttech/docs/egenfeldt.pdf

Emin-Martinez, V., \& Ney, M. (2013). Supporting teachers in the process of adoption of game based learning pedagogy. In P. Escudeiro, \& C. Vaz de Carvalho (Eds.), The Proceedings of the 7th European Conference on Games Based Learning (ECGBL 2013) (pp. 45-52). Porto, Portugal. Retrieved from https://hal.archives-ouvertes.fr/hal-00872282/document

Ersöz, A. (2000). Six games for the EFL/ESL classroom. The internet TESL Journal, 6(6), 1-4. Retrieved from http://iteslj.org/Lessons/Ersoz-Games.html

Fisher, M. C. (2011). Dictation: What and how students learn from it (Master's thesis). School for international Training, Brattleboro, Vermont, USA. Retrieved from http://digitalcollections.sit.edu/cgi/viewcontent.cgi?article=1420\&context=ipp_collection

Funk, H. (2011). Prinzipien und standards des DaF-Unterrichts-und einige überlegungen zum stellenwert der grammatik [PowerPoint slides]. $\quad$ Retrieved from http://www.dafdaz.uni-jena.de/iadfdzmedia/Team/Professuren/Prof_+Dr_+Hermann+Funk/Downloads/Tel aVivdownload.pdf

Gee, J. P. (2003). What video games have to teach us about learning and literacy. Computers in Entertainment, 1(1), 1-20.

Gerber, H. R., \& Price, D. P. (2013). Fighting baddies and collecting bananas: Teachers' perceptions of games-based literacy learning. Educational Media International, 50(1), 51-62.

Glaboniat, M., Müller, M., Rusch, P., Schmitz, H., \& Wertenschlag, L. (2008). Profile Deutsch. München: Langenscheidt.

Goethe Institute. (2011). Adventure German-The Mystery of the Nebra Sky Disc. Retrieved from https://www.goethe.de/en/spr/ueb/him.html

Goethe Institute. (2013). Adventure German-A Mysterious Mission. Retrieved from https://www.goethe.de/en/spr/ueb/mis.html

Guillén-Nieto, V., \& Aleson-Carbonell, M. (2012). Serious games and learning effectiveness: The case of It's a Deal! Computers \& Education, 58, 435-448.

Harriehausen-Mühlbauer, B., Prados, F. J. R., Ludwig, B., \& Ott, H. (2006). Spielend lernen mit dem Handy. Querschnitt, 2006, 78-87. Retrieved from https://www.fbi.hda.de/fileadmin/personal/b.harriehausen/Forschungsprojekte/SigmaStar/art/Querschnitt_2 $0 . p d f$

Howland, R., Urano, S., \& Hoshino, J. (2012). SanjigenJiten: Computer assisted language learning system within a 3D game environment. In A. Nijholt, T. Romão, \& D. Reidsma (Eds.), Advances in Computer Entertainment-Proceedings of 9th International Conference (ACE 2012) (pp. 262-273). Katmandu, Nepal.

Jantke, K. P., \& Hume, T. (2015). Effective learning through meaning construction in digital role playing games. In The Proceedings of the $5^{\text {th }}$ IEEE International Conference on Consumer Electronics. Berlin, Germany. Retrieved from http://ieeexplore.ieee.org/stamp/stamp.jsp?arnumber=7066566

Karadag, R. (2015). Pre-service teachers' perceptions on game based learning scenarios in primary reading and writing instruction courses. Educational Sciences: Theory \& Practice, 15(1), 185-200.

Kirriemuir, J., \& McFarlane, A. (2004). Literature review in games and learning. In A NESTA Futurelab Research report-report 8. Retrieved from https://hal.archives-ouvertes.fr/hal-00190453/document

Kocaman, O., \& Kizilkaya-Cumaoglu, G. (2014). The effect of educational software (denis) and games on vocabulary learning strategies and achievement. Education and Science, 39(176), 305-316.

Krashen, S. D. (1985). The input hypothesis: Issues and implications. Harlow: Longman.

Lacasa, P., Méndez, L., \& Martínez, R. (2008). Bringing commercial games into the classroom. Computers and Composition, 25, 341-358. 
Levy, R. M., \& O’Brien, M. G. (2006). A virtual world for teaching german. Loading, 1(1), 1-17. Retrieved from http://journals.sfu.ca/loading/index.php/loading/article/view/14/12

Mei, P. (2013). A preliminary study on the validity of english passage dictation test. US-China Foreign Language, 11(5), 349-354. Retrieved from http://www.davidpublisher.com/Public/uploads/Contribute/552f72182f3dc.pdf

Millstone, J. (2012). Teacher attitudes about digital games in the classroom. Paper presented at Sesame Workshop in the Joan Ganz Cooney Center. Retrieved from http://www.joanganzcooneycenter.org/wp-content/uploads/2012/07/jgcc_teacher_survey1.pdf

Müller, A. (2012). Research-based design of a medical vocabulary videogame. International Journal of Pedagogies and Learning, 7(2), 122-134.

Neugebauer, C., \& Nodari, C. (1999). Aspekte der sprachförderung. In M. Gyger, \& B. Heckendorn-Heiniman (Eds.), Erfolgreich integriert? Fremd-und mehrsprachige Kinder und Jugendliche in der Schweiz (pp. 161-175). Bern: Bernischer Lehrmittel-und Medienverlag.

Neville, D. O. (2010). Structuring narrative in 3D digital game-based learning environments to support second language acquisition. Foreign Language Annals, 43(3), 446-469.

Neville, D. O. (2015). The story in the mind: The effect of 3D gameplay on the structuring of written L2 narratives. ReCALL, 27, 21-37.

Noraddin, E. M., \& Kian, N. T. (2013). Academics' attitudes toward using digital games for learning \& teaching in Malaysia. MOJET, 2(4), 1-21. Retrieved from http://www.mojet.net/frontend/articles/pdf/v02i04/v02i04-01.pdf

Oller, J. W. (1979). Language tests at school. London: Longman.

Pawłowska, A. (2012). Zur bedeutung des fremdsprachlichen schreibens. Einige überlegungen aus der theorie und praxis des daf-unterrichts auf der fortgeschrittenenstufe. Glottodidactica, 39(1), 69-79.

Peirce, N., \& Wade, V. (2010). Personalised learning for casual games: The "Language Trap" online language learning game. In B. Meyer (Ed.), Proceedings of the 4th European Conference on Games Based Learning (ECGBL 2010) (pp. 306-315). Copenhagen, Denmark: Academic Publishing. Retrieved from http://www.tara.tcd.ie/handle/2262/41244

Peterson, M. (2012). Learner interaction in a massively multiplayer online role playing game (MMORPG): A sociocultural discourse analysis. ReCALL, 24, 361-380.

Piechotta, J., \& Beck, R. (2006). Anregungen und entscheidungshilfen für die methodenauswahl im fremdsprachenunterricht-Materialien zur Umsetzung des Rahmenlehrplans Grundschule Fremdsprachen in der Grundschule. Ludwigsfelde-Struveshof: LISUM Bbg.

Prensky, M. (2001). Digital natives, digital immigrants Part 1. On the Horizon, 9(5), 1-6.

Purushotma, R. (2005). Commentary: You're not studying, you're just. Language Learning \& Technology, 9(1), 80-96. Retrieved from http://ltt.msu.edu/vol9num1/pdf/purushotma.pdf

Rama, P., Black, R., Van Es, E., \& Warschauer, M. (2012). Affordances for second language learning in World of Warcraft. ReCALL, 24, 322-338.

Rayner, M., \& Tsourakis, N. (2013). Methodological issues in evaluating a spoken call game: Can crowdsourcing help us perform controlled experiments? In P. T. Badin, H. G. Bailly, D. Demolin, \& F. Raby (Eds.), Proceedings of the Workshop on Speech and Language Technology in Education (SLaTE 2013) (pp. 77-82). Grenoble, France. Retrieved from https://archive-ouverte.unige.ch/unige:30953

Robertson, J., \& Cathrin, H. (2008). Computer game design: Opportunities for successful learning. Computers \& Education, 50, 559-578.

Roy, M., \& Schlemminger, G. (2014). Immersion und interaktion in virtuellen realitäten: Der faktor präsenz zur optimierung des geleiteten sprachenlernens. Zeitschrift für Interkulturellen Fremdsprachenunterricht, 19(2), 187-201. Retrieved from http://tujournals.ulb.tu-darmstadt.de/index.php/zif/article/view/39/36

Sandford, R., Ulicsak, M., Facer, K., \& Rudd, T. (2006). Teaching with games-Using commercial off-the-shelf computer games in formal education. Bristol: Futurelab. Retrieved from https://www.nfer.ac.uk/publications/FUTL49/FUTL49.pdf 
Sørensen, B. H., \& Meyer, B. (2007). Serious games in language learning and teaching-A theoretical perspective. Retrieved from http://www.digra.org/wp-content/uploads/digital-library/07312.23426.pdf

Stanley, G., \& Mawer, K. (2008). Language learners \& computer games: From space invaders to second life. The Internet TESL Journal, 11(4), 1-12. Retrieved from http://files.eric.ed.gov/fulltext/EJ898143.pdf

Stewart, J., Bluemers, L., Van Looy, J., Mariln, I., All, D. S., Schurmans, D., ... Misuraca, G. (2013). The potential of digital games for empowerment and social inclusion of groups at risk of social and economic exclusion: Evidence and opportunity for policy. In C. Centano (Ed.), JRC Scientific and Policy Reports. EUR 25900 EN, Luxembourg: Publication Office of the European Union. Retrieved from http://ftp.jrc.es/EURdoc/JRC78777.pdf

Sykes, J. M., Oskoz, A., \& Thorne, S. L. (2008). Web 2.0, Synthetic immersive environments, and mobile resources for language education. CALICO Journal, 25(3), 528-546. Retrieved from https://calico.org/html/article_715.pdf

Sylvén, L., \& Sundqvist, P. (2012). Gaming as extramural English L2 learning and L2 proficiency among young learners. ReCALL, 24(3), 302-321.

Turkle, S. (2005). Computer games as evocative objects: From projective screens to relational artifacts. In J. Raessens, \& J. Goldstein (Eds.), Handbook of Computer Game Studies (pp. 268-279). Cambridge et al.: MIT. $\quad$ Retrieved from http://web.mit.edu/sturkle/www/pdfsforstwebpage/ST_Computer\%20Games\%20as\%20Evoc\%20Obj.pdf

Wagner, M., \& Mitgutsch, K. (2009). Endbericht des projekts didaktische szenarien des digital game based learning. Donau-University. Retrieved from http://www.donau-uni.ac.at/imperia/md/content/department/imb/acgs/endbericht_dsdgbl.pdf

Wastiau, P., Kearney, C., \& Van den Berghe, W. (2009). How are digital games used in schools-Final report (A. Joyce, P. Gerhard, \& M. Debry, Eds.). Praha: Hofi Studio. Retrieved from http://games.eun.org/upload/gis-full_report_en.pdf

Wright, A., Betteridge, D., \& Buckby, M. (1984). Games for language learning. Cambridge: CUP.

Yilmaz-Ince, E., \& Demirbilek, M. (2013). Secondary and high school teachers' perceptions regarding computer games with educational features in Turkey. Anthropologist, 16(1-2), 89-96. Retrieved from http://krepublishers.com/02-Journals/T-Anth/Anth-16-0-000-13-Web/Anth-16-1-2-000-2013-Abst-PDF/TANTH-SV-10-089-13-09/T-ANTH-SV-10-089-13-09-Tx[9].pmd.pdf

\section{Copyrights}

Copyright for this article is retained by the author(s), with first publication rights granted to the journal.

This is an open-access article distributed under the terms and conditions of the Creative Commons Attribution license (http://creativecommons.org/licenses/by/4.0/). 